\title{
LICET, LICET, LICENTIA
}

\section{Кратика сорржина}

Во класичниой лайински именкайа licentia іи има значењайа „слобояа, оозвола, самоволие“, а ілаіолой licet значи „яозволено е, слобооно е, може“. Преомей на анализа на овој йруя се явайа најсииари книжевни иримери оя именкайа licentia кои се срекаваай кај комеоиоірафой Плауй. Анализайа иокажува оека значењетио на именкайа licentia во иірайа со зборови во шесйайа сиена оя чейвриииой чин на комеоијайа „Јаже“ е сосема различно оя иииичинойо значење на оваа именка во класичниой лаииински. Доколку не се рабоиии само за иренесување на значењейо „може“ оя ілаіолой на именкайа, итоіам можеби иреку оваа иіра со зборови Плауй свеоочи за еяен иоорхаичен стиаяиум во семанииичкиой развој на именкайа licentia, ояносно за еииимолошкайа йоврзаносии на ілаіолите licet, „,озволено е, слобояно е, може“, и liceо, „на иррояажба сум, вреоам, имам иена“.

\section{Клучни зборови: LICET, LICENTIA, ПЛАУТ, ИГРИ СО ЗБОРОВИ}

Слободата со која римскиот комедиограф Плаут си поигрува со зборовите и со нивните значења има многу лица и многу облици. Во оваа прилика тоа ке го илустрираме со еден пример од комедијата Rudens, „Јаже“, каде што предмет на игра е токму именката licentia, „слобода“" и глаголот licet, „дозволено е, слободно е, може“.

Во шестата сцена од четвртиот чин на комедијата „Јаже“ разговараат Даемон, татко на девојката Палаестра и Трахалион, роб на момчето Плесидип, кому Даемон сака да му ја даде својата ќерка за жена. Во разговорот постојано се повторува глаголот licet. Најпрвин Даемон му дава заповеди на Трахалион, а Трахалион му одобрува и се согласува постојано повторувајќи licet, во смисла „може, во ред“. А потоа Трахалион му ги поставува своите барања на Даемон, па сега тој се согласува и постојано повторува licet. Но на крајот од сцената не може да се воздржи и ѝ се обраќа на публиката со експлозивен коментар, сп. Pl.Rud.1224-1226:

\section{... Da. licet.}

Hercules istum infelicet cum sua licentia!

ita meas replevit auris quidquid memorabam 'licet'.

\section{„Даем. Може.}

О, да даде Херкул да снеможе и тој и неговото можење.

Ушиве ми ги дупна со тоа, сѐ што спомнав „може“, „може“. 
Именката licentia, за нас позната преку латинизмот лиценца, „дозвола, одобрение, овластување“, во значењето „слобода“ се среќава кај различни книжевни автори во класичниот латински јазик. Во позитивна смисла тоа е „дозвола, допуст, одобрение“ слобода што произлегува од почитувањето на општествените и правните норми. Во негативна смисла тоа е „самоволие, разузданост, неумереност“, слобода што произлегува од пречекорувањето на општествените и правните норми (види $O L D 1028$ ). И едното и другото значење се надоврзуваат на значењето на глаголот licet, „дозволено е, допуштено е, слободно е, може“, од кој е изведена оваа именка, сп. кај Кикерон: licere id dicimus, quod legibus, quod more maiorum institutisque conceditur. Neque enim quod quisque potest, id ei licet. (Cic. Phil.13.6.14), „дозволено е, велиме, она, што е допуштено со законите, она што е допуштено со обичаите и одредбите на предците. А не, на секој што му се може, тоа да му биде допуштено." и иt enim pueris non omnem ludendi licentiam damus, sed eam, quae ab honestatis actionibus non sit aliena .... (Cic. Off.1.29.103), „како што на децата не им даваме секаква слобода за играње, туку само таква, што не е отуѓена од чесното однесување...", сп. и кај Корнелиј Непот ..... multa secum reputans de immoderata ciuium suorum licentia crudelitateque erga nobiles ... (Nep. Alc.4.4), „... размислувајќи многу за неумереното самоволие на своите граѓани и суровоста кон благородниците... “.

Што се однесува до ранолатинскиот, најстарите два примера од именката licentia, всушност, ги имаме кај Плаут. Значењето „слобода, дозвола“ и „дозволено е“ е потврдено во комедијата Trinummus, „Тригрошец“, сп. Pl.Trin.1032-1035:

Nam nunc mores nihili faciunt quod licet, nisi quod lubet:

ambitio iam more sanctast, liberast a legibus;

scuta iacere fugereque hostis more habent licentiam:

petere honorem pro flagitio more fit.

„Денес е вообичаено да не се грижиш дал' е дозволено, ако е пожелно:

стремежот веќе ги има благословот на обичаите и слободата на законите;

Штитот да го фрлиш и од непријателот да бегаш дозвола ти даваат обичаите:

Почести да бркаш заради бесчестие стана обичај.“

Овој пример добро го илустрира амбивалентниот карактер на поимот слобояа и неговата поврзаност со амбивалентниот карактер на она што е обичај и вообичаено.

Значењето, пак, на именката licentia во цитираниот пример од комедијата „Јаже“, очигледно, е поинакво. Плаут тука прави една игра со значењата на зборовите и на именката licentia го пренесува значењето „може, договорено, важи“ од глаголот licet, односно значењето „постојано повторувам licet“. Глаголската форма infelicet, слично, не значи буквално „унесреќува, прави некого несреќен“, туку „прави да престане да повторува

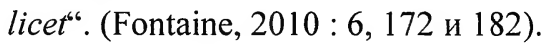

\footnotetext{
' Сп. го преводот на македонски „Како што на детето не му дозволуваме да се впушти во секоја игра, туку само во онаа којашто не отстапува од однесувањето коешто е во склад со чесноста..." (Кикерон, За оолжносииииее (превод од латински на македонски Светлана Кочовска), Скопје 2005.
} 
Но, дали е ова сѐ или, сепак, преку оваа игра со зборови можеме да откриеме и нешто повеќе за семантичкиот развој на именката licentia и глаголот licet?

Именката licentia е изведена од партиципската основа licent- на глаголот licet. ${ }^{2} \mathrm{Ce}$ смета дека овој глагол е семантички споредлив со глаголите liceo, „на продажба сум, вредам, имам цена“, и liceor, „предлагам цена, се наддавам“, и дека е изведен од истата

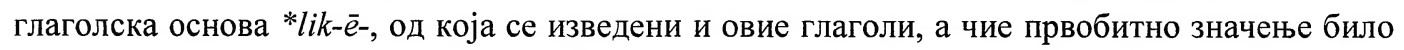
„на понуда е, достапно е, вреди, чини“ (Nussbaum, 1994 : 162 и понатаму, EDL 340). Нема паралели во другите индоевропски јазици $(E D L 340){ }^{3}$

Семантичката игра на Плаут можеби не е само во тоа што кај именката licentia го имплицира значењето „кажувам постојано licet“, туку и во тоа што на глаголот licet го пренесува значењето што го има глаголот liceo, „на продажба сум, вредам, имам цена“. Семантичката врска помеѓу глаголот што се употребува за да се искаже согласност во најопшта смисла „важи (има важност, вреди), договорено е“ и глаголот што се употребува за да се искаже дека нештото што се нуди за продажба има определена вредност (важност) е разбирлива. Глаголот liceo се среќава и кај Плаут, сп. Pl. Men. 1158-1159:

venibunt servi, supellex, fundi, aedes, omnia.

venibunt quiqui licebunt, praesenti pecunia.

Робови, предмети, мебел, имот, згради, сѐ ке се продава.

Колку што ќе вреди, за толку ќе биде продадено, за пари во готово.

А контекстот на шестата сцена од четвртиот чин на „Јаже“ дозволува licet да се разбере и како форма од liceo, зашто разговорот помеѓу Трахалион и Даемон, всушност, е преговарање. Трахалион се согласува да ги исполни заповедите на Даемон, но во исто време и му кажува дека тоа има своја цена. Во еден момент, разговорот и навистина добива пресврт, кога Трахалион му вели на Даемон: „Ама, знаеш што сакам од тебе јас?“, па сега започнува тој да ги поставува своите услови, а Даемон да се согласува и одобрува, сп. Pl.Rud.1216-1217:

Daem. Omnian licet? Trach. Licet. sed scin quid est quod te volo? quod promisisti ut memineris, hodie ut liber sim. Daem. Licet.

Даем. Сѐ ли може? Трах. Може. Ама, знаеш што сакам од тебе јас? Што си ми ветил, да се сетиш, дека од денес сум слободен. Даем. Може.

Во тој случај, пренесеното значење на именката licentia ќе биде поврзано и со глаголот liceo, а Даемон со својот коментар на крајот од сцената практично укажува на

\footnotetext{
${ }^{2}$ Изведувањето апстрактни именки од основата на активниот партицип на презентот е продуктивно во латинскиот јазик, сп. praesent-ia, „сегашност“ (од praesens, „присутен“, praesum, „присутен сум“); sapient-ia, „мудрост, знаење“ (од sapiens, „мудар, умен, мудрец“, sapio, „чувствувам, знам“). Види, Leumann, 1977: 291.

${ }^{3}$ Споредбата со латв. likkstu, likku, likkt, „се договара“ (IEW : 669) не е сосема извесна, види Nussbaum, $1994: 187$.
} 
расположливоста (податливоста) на робот Трахалион, односно на неговата важност, вредност. Ако е така, стиховите 1224-1226 би можеле да ги преведеме и на следниов начин:

... Da. licet.

Hercules istum infelicet cum sua licentia!

ita meas replevit auris quidquid memorabam 'licet'.

„Даем. Важи.

О, да даде Херкул да не важи и тој и важноста негова!

Ушиве ми ги дупна со тоа, сѐ што спомнав „важи“, „важи“.

Ако е прифатливо ваквото толкување на овие стихови, тогаш во нив имаме важно сведоштво за тоа дека семантичката и етимолошката поврзаност на глаголите licet и liceo во времето на Плаут се чувствувала во поголема мера, а именката licentia можеби имала и едно поконкретно значење, поврзано со глаголот liceo. 


\section{Литерапиура}

Изворни и преводни изданија

T. Macci Plauti Comoediae, Tomus I, ed. W.M. Lindsay, Oxonii, 1988 (репринт на изданието од 1904).

T. Macci Plauti Comoediae, Tomus II, ed. W.M. Lindsay, Oxonii, 1990 (репринт на изданието од 1905).

Plautus, III, ed. T. E. Page et al., with an English translation by Paul Nixon, London - Cambridge, Massachusetts, 1963.

Plautus' comedies = Plautus's comedies Amphitryon, Epidicus and Rudens. London: 1694.

\section{Друга литература}

$\mathrm{DELG}=\mathrm{P}$. Chantraine, Dictionnaire étimologique de la langue grecque, $\mathrm{I}-\mathrm{IV}_{2}$, Paris 1968-1980.

Duckworth, 1994 : Duckworth, G.E., The Nature of Roman Comedy: a study in popular entertainment (with a foreword and bibliographical appendix by Hunter, R.), sec.ed., Uuniversity of Oklahoma Press, Norman.

$\mathrm{EDL}=\mathrm{M}$. de Vaan, Etymological Dictionary of Latin and the other Italic Languages, LeidenBoston 2008.

Fontaine, 2010 : Fontaine, M., Funny words in Plautine Comedy, Oxford.

Fraenkel, 2007 : Fraenkel, E., Plautine Elements in Plautus. Oxford: University Press.

IEW = J. Pokorny, Indogermanisches etymologisches Wörterbuch, I-II, Bern - München, 1959 1965.

Leumann, 1977 : Leumann, M., Lateinische Laut- und Formenlehre, München.

Meiser, 2006 : Meiser, G., Historische Laut- und Formenlehre der lateinischen Sprache, 2 Aufl, Darmstadt.

Mendelsohn, 1907 : Mendelsohn, Ch. J., Studies in the Word-Play in Plautus, Philadelphia.

Nussbaum, 1994 : Nussbaum, A. "Five Latin Verbs from a Root *leik-", Harvard Studies in Classical Philology 96, pp. 161-191.

OLD $=$ A. Souter et al., Oxford Latin Dictionary, Oxford 1968.

Westaway 1917 : Westaway, K. M., Original Element in Plautus. Cambridge: University Press 1917. 


\section{Elena DŽUKESKA}

\section{LICET, LICET, LICENTIA}

\section{Summary}

In Classical Latin the noun licentia means "freedom, permit, immoderate behaviour" and the verb licet means "it is permitted, one may, it is all right". Subject of analysis in this work are the two oldest literary examples of the noun licentia found in the works of the Roman playwright Plautus. The analysis shows that the meaning of the noun licentia used in a wordplay in the sixth scene of the fourth act of the comedy "Fisherman's Rope" is completely different from the typical meaning of this noun in Classical Latin. Unless this is just a case of transferring the meaning "one may" from the verb to the noun, than perhaps Plautus in this wordplay testifies of an older stage in the semantical development of the noun licentia i.e. of the etymological relationship between the verbs licet, "it is permitted, one may, it is all right" and liceo, "to fetch".

Keywords: LICET, LICENTIA, PLAUTUS, WORDPLAY 